\title{
Lise Öğretmenlerinin Örgütsel Adalet ve İş Doyumu Algıları Arasındaki İlişki Düzeyleri*
}

\author{
Zülfü DEMİRTAŞ ${ }^{1}$, Yılmaz KILIÇ ${ }^{2}$
}

${ }^{1}$ Doṣ. Dr. Zülfü Demirtaș Firat Üniversitesi Ë̆itim Fakültesi Eğitim Bilimleri Bölümü zdemirtas@firat.edu.tr 2 Okt. Yllmaz Kllig B. E. Ü. Adilcevaz.Meslek.Yüksekokulu kilii0442@gmail.com

$\mathrm{Bu}$ araștırmada lise öğretmenlerinin örgütsel adalet ve iș doyumu algıları arasındaki ilișki incelenmiștir. Araştırmada Minnesota Doyum ve Örgütsel Adalet ölçekleri kullanılmıştır. Ölçeklerden elde edilen bulgular, katılımcıların örgütsel adaletin bütün boyutlarında "Katılıyorum" düzeyinde; İs Doyumu Ölçeğinde yer alan maddelere "Kararsızım" ve "Memnunum" düzeylerinde görüşlere sahip olduklarını göstermektedir. İş doyumu ile örgütsel adaletin üç alt boyutu arasında .01 düzeyinde anlamlı bir ilişki vardır. İş doyumu ile dağıtımsal adalet, işlemsel adalet ve etkileşimsel adalet boyutları arasındaki ilişki orta düzeyde anlamlı ve pozitiftir. Diğer taraftan, örgütsel adaletin alt boyutları arasındaki ilişki, bu boyutlanın iş doyumu ile olan ilişkisinden daha güçlüdür. Örgütsel adalet ve iş doyumu arasında olumlu ve anlamlı bir ilişki vardır. Örgütsel adalet algı düzeylerinin yüksek olduğu iş yerlerinde iş doyumu algı düzeyleri de yüksektir.

Anahtar Kelimeler: Adalet, Örgütsel Adalet, İş Doyumu, Örgütsel Adalet ile İş Doyumu İlişkisi.

\section{The Relationship Levels Between Perceptions of Organizational Justice and Job Satisfaction of Lycee Teachers}

\begin{abstract}
In this study the relationship between the perceptions of organizational justice and job satisfaction of lycee teachers was examined. Minnesota Satisfaction and Organizational Justice scales were used in research. Findings obtained from scales, in all dimensions of organizational justice participants opined at level "I agree" and it showed that participants had had perspective at levels of "I am neutral" and "I am pleased" on items in job satisfaction scale. There is a significant relationship between job satisfaction and three sub-dimensions of organizational justice at level of 0,1 . The relationship between job satisfaction and sub-dimensions of organizational justice is significant and positive at medium level. On the other hand, the relationship between the sub-dimensions of organizational justice is stronger than the relationship related to job satisfaction. There is a positive and very significant relationship between organizational justice and job satisfaction. The levels of perception of job satisfaction are also high in the workplaces where the levels of perception of organizational justice are high.
\end{abstract}

Key words: Justice, Organizational Justice, Job Satisfaction and The relationship of Organizational Justice and Job Satisfaction.

\section{GİRİ̧̧}

Adaletin mülkün (yönetimin) temeli olduğu düşüncesinin dünyadaki bütün toplumları ilgilendirdiği kadar Türk ve İslam toplumlarını da yakından ilgilendirdiği söylenebilir. Adalet kavramı Gültekin (1983: 25) tarafından, insan haklarına saygı gösterme, herkesi eşit tutma ve herkese hakkını verme olarak tanımlanmaktadır. Adaletin, insan topluluklarının temelini oluşturduğuna inanılır. Toplumda var olan adalet ve adalet algisının örgütlerde olmaması söz konusu olamaz. Örgütlerdeki bu adalet alg1sı "örgütsel adalet" kavramı ile karşılanmaktadır. İşcan ve Naktiyok ( 2004: 7) örgütsel adaleti, uzun süreden beri işgörenlerin kişisel doyumu ve etkin örgütsel fonksiyonlar bağlamında temel bir gereklilik olarak görmektedirler. Adaletli bir örgütte işgörenler, yöneticilerin davranışlarını adil, ahlaki ve rasyonel olarak değerlendirirler. İşgörenlerin

\footnotetext{
* Bu makale, Doç. Dr. Zülfü Demirtaş'ın danışmanlığında Yılmaz Kılıç tarafından hazırlanan ve 2013 yılında Fırat Üniversitesi Eğitim Bilimleri Enstitüsü tarafından kabul edilen "Lise öğretmenlerinin örgütsel adalet ve iş doyumu algıları arasındaki ilişki” başlıklı tezden türetilen ve 07-09 Mayıs 2015 tarihlerinde Gaziantep’te düzenlenen 10. Ulusal Eğitim Yönetimi Kongresinde sözlü olarak sunulan bildirinin genişletilmiş halidir.
} 
örgütteki uygulamaların adilliğine ilişkin algılamaları, onlanın örgüt ve yöneticilerine duydukları bağlılığı ve güveni etkiler. Yapılan uygulamaların ve elde edilen kazanımların adilliği, yöneticilerin işgörenlerin haklarına ve kişisel değerlerine duydukları saygının bir göstergesi olarak kabul edilir (İşbaşı, 2000: 42). Örgütsel adalet üç başlık altında gruplandırılabilir: dağıtımsal, işlemsel ve etkileşimsel adalet.

Dağıtımsal adalet, Adams'ın eşitlik kuramına dayanır. Adams'a göre bireylerin endişeleri mutlak sonuçlarla değil, sonuçların adil olup olmadığı ile ilgilidir (Bakhshi, 2009: 146). Dağıtımsal adalet, işgörenlerin ücret, terfi gibi kazanımların dağıtımıyla ilgili yönetimsel kararların adilliğini içerir (Eren, 2011: 576). Dağıtımsal adalette esas olan, bireylerin, dağıttlan kaynaklardan adil şekilde pay aldığını düşünmesidir (Özdevecioğlu, 2003: 78)

İşlemsel adalet, doğru yöntem ve rehberler yardımıyla gerçekleştirilen dağıtım kararlarından etkilenme derecesi olup, karar vermede doğru süreçlerin algılanması ile ilgilidir (Sayın, 2009: 11). İşlemsel adalet nesnel veya Öznel durumlarla ilgili olabilir. Nesnel işlemsel adalet fiili veya maddi adalet ile ilgili iken; öznel işlemsel adalet de nesnel işlemlerin algılanışı veya nesnel bir işlemin adalet yargısını artırabilme kapasitesi ile ilgilidir (Akt. Eker, 2006).

Etkileşimsel adalet, süreçleri uygulamakla görevli kişilerin, karşı tarafa gösterdikleri tutum ve davranışlarla ilgili olup, süreç adaletine bağlı bir ek boyut olarak gelişmiştir (Söyük, 2007: 13). Kararlanı düzenleyen biçimsel süreçlerin algılanan adaleti olarak tanımlanan süreç adaleti üzerinde yapılan çalışmaların ilerlemesiyle birlikte, araşturmacıların adalet algısının belirlenmesinde bir başka faktörün önemini fark etmeleriyle etkileşimsel adalet olarak isimlendirilen yeni bir adalet türü ortaya çıkmıştır. İşgörenlerin adalet algısının oluşmasında, süreçlerin uygulanması esnasında kişilerin karşılaştı̆ı bireylerarası etkileşimin kalitesinin de göz önünde bulundurulması gerektiği ileri sürülmüş ve bu durum etkileşimsel adalet olarak tanımlanmıştır (Yürür, 2008: 298).

İş doyumu, küresel bir yapı ve çok boyutlu bir kavram olarak tanımlanan ve ölçülen (Lund, 2003), işgörenin işin farklı boyutlarına ilişkin gereksinme, beklenti veya isteklerinin iş tarafindan karşılanmasına ilişkin algısının onda uyandırdığı bir duygu (Demirtaş \& Ersözlü, 2010: 200) olup, işgörenin işine yönelik bireysel olarak verdiği tepkiyi ifade eder. Başka bir ifadeyle, iş doyumu, bireyin beklediği veya arzuladığı çıktılarla gerçekleşen çıktılar arasında yaptığı karşılaştırma sonucunda işine karşı beslediği duygusal tepki olup (Cranny, Smith \& Stone, 1992: 1) işe karşs geliştirilen tutumu (Brief, 1998: 10) duyguları, düşünceleri ve tecrübeleri içerir (Lawler,1987). Bununla birlikte işgörenin mesai arkadaşları ile olan ilişkileri, örgütsel uygulamalar, denetim, çalışma koşulları, terfi ve ödeme ile ilgili özel yönler (Misener, Haddock, Gleaton \& Ajamieh, 1996) çalışma desteği, iş özerkliği sağlama ve bireyin memnuniyeti (Agho, Mueller \& Price, 1993; Hundley, 2001) iş doyumu kapsaminda ele alınmaktadir.

Örgüt ortamında örgütsel adalet algısı ile iş doyumu arasında anlamlı bir ilişki olması beklenmektedir. Örgütsel kaynakların adil bir şekilde dağıtıldığına yönelik algısının yüksek olmasının işgörenlerin iş doyumlarının artacağına inanılır. İş doyumu ya da doyumsuzluğu, kişinin güdülenmesi ile ilgili olduğu gibi işgörenin kendisi, işin özellikleri ve iş çevresi ile ilgili çok sayıda faktörden etkilenerek ortaya çıkmaktadır (Demirtaş, 2010: 186).

Farklı işgören grupları arasında iş doyumu ve örgütsel adaletin önemi giderek artmaktadır. Bu işgören gruplarından biri de eğitim kurumlarında çalışan öğretmenlerdir. Bu alanda yapılan araştırma sonuçlarına göre öğretmenlerin eğitim vermek amacıyla sürekli öğrencilerle iletişim halinde bulundukları, eğitim ve öğretim ihtiyaçlarını karşılamak için baskı ve strese girdikleri, ihtiyaçlarının karşılanmamasıyla birlikte motivasyonlarının azaldığ1 belirtilmektedir (Akt. Karakuş, 2008: 10).

Eğitim örgütlerinde görev yapanların yüksek motivasyona sahip olması, bu örgütlerin etkili ve verimli çalışmasına ortam hazırlar. Okulların etkili ve verimli bir ortama ulaşabilmesi için örgütlerin temel taşı niteliğindeki öğretmenlerin iş doyumlarının yüksek olması gerekir. Okullarda öğretmenlerin sağladığı doyum ya da doyumsuzluk eğitim-öğretimin kalitesi bakımından büyük önem taşımaktadır (Demirtaş \& Ersözlü, 2010: 202). Eğitim sisteminin işlevini yerine getirebilmesi, eğitim organizasyonlarının etkililiğine bağlıdır. Eğitim 
kurumlarının etkililiği ise örgütsel amaçların gerçekleştirilmesinde hammaddesi ve ürünü insan olan bir örgütte görev alan öğretmenlerle gerçekleştirilebilir. (Özgan \& Bozbayındır, 2011: 68).

$\mathrm{Bu}$ bağlamda liselerde görev yapan öğretmenlerle ilgili bir araştırma yapılmıştır. Bu araştırmanın genel amacı, liselerde görev yapan öğretmenlerin örgütsel adalet ve iş doyumu algıları arasındaki ilişkiyi araştırmaktır. Bu genel amaca ulaşabilmek için aşağıdaki alt problemlere cevap aranmıştur:

1. Lise öğretmenlerinin örgütsel adalet algıları ne düzeydedir?

2. Lise öğretmenlerinin iş doyumu ne düzeydedir?

3. Lise öğretmenlerinin örgütsel adalet ile iş doyumu arasında anlamlı bir ilişki var mıdır?

\section{YÖNTEM}

\subsection{Araştırma Modeli}

$\mathrm{Bu}$ araştırma nicel yaklaşım kapsamında olan ilişkisel tarama modelinde tasarlanmıştır. İlişkisel tarama modelleri, iki ve daha çok sayıdaki değişken arasında birlikte değişimin varlığını ve/veya derecesini belirlemeyi amaçlayan araştırma modelleridir (Karasar, 2011: 81). Bu tür araştırmalar, "ne, nerede, ne zaman, hangi aralıkta, hangi düzeyde, nasıl” gibi sorulara cevap vermeye çalışır (Büyüköztürk, 2014: 177). Bu model doğrultusunda lise öğretmenlerinin örgütsel adalet ve iş doyumu algıları ile bu iki kavram arasındaki ilişki incelenmiştir.

\subsection{Evren ve Örneklem}

Araştırmanın evreni 2012-2013 öğretim yılında Bitlis ilinde eğitim-öğretim faaliyetlerini aktif bir şekilde sürdürmekte olan liselerde görev yapan 888 öğretmen oluşturmaktadır. Araştırmanın örneklemini, Bitlis merkez, Adilcevaz, Ahlat ve Tatvan ilçelerinde bulunan liselerde görev yapan öğretmenler oluşturmaktadır. Öğretmenlerin yoğun olduğu ve ulaşılması kolay olan yerler örneklem olarak seçilmiştir. Örnekleme kapsamına alınan liselere 530 ölçek gönderilmiş ve 420 ölçek geri dönmüştür. Geri dönen ölçeklerden 19 tanesi değerlendirme dışı tutulmuştur. Değerlendirmeye alınan 401 ölçek evrenin \% 45’ni oluşturmaktadır.

\subsection{Veri Toplama Araçları}

Araştırmada veri toplama aracı olarak Örgütsel Adalet Ölçeği (Justice Scale) ve Minnessota Doyum Ölçeği (Minnessota Satisfaction Questionnaire) kullanılmıştır. Ölçekler için yapılan geçerlilik ve güvenirlik analizleri aşağıda belirtilmiştir.

2.3.1. Örgütsel Adalet Ölçeği: Öğretmenlerin örgütsel adalet alg1larını ölçmek üzere, Niehoff \& Moorman (1993) tarafindan geliştirilen ve Yıldırım (2007) tarafından mühendislere ve işgörenlere uygulanan; dağıtımsal, işlemsel ve etkileşimsel adalet olmak üzere üç boyuttan oluşan Örgütsel Adalet Ölçeği kullanılmıştır. Dağıtımsal Adalet, farkı iş sonuçlarının ücret düzeyi, iş yükü, iş sorumlulukları ve adilliği tayin eden beş maddeden oluşmaktadır. İşyerinde karar alma mekanizmalarını ölçen İşlemsel Adalet Ölçeği alı maddeden oluşmaktadır. Etkileşimsel Adalet Ölçeği, dokuz maddeden oluşmaktadır. Bu maddeler, işgörenlerin kendi ihtiyaçlarının dikkate alındığını ne kadar hissettiklerini ve iş kararları için yeterli açıklamanın ne kadar yapıldığını ölçmektedir (Yıldırım, 2007: 264). Örgütsel Adalet ölçeğinin orijinal formu için hesaplanan güvenirlik Cronbach Alpha katsayıları Dağıtımsal Adalet .81, İşlemsel Adalet .89 ve Etkileşimsel Adalet için .95’dir (Niehoff \& Moorman, 1993). Mevcut araştırma için her bir faktör ve ölçeğin toplamı için güvenirlik katsayıları hesaplanmıştır. Bu katsayılar Dağıtımsal boyutunda .72, İşlemsel Adalet boyutunda .64 ve Etkileşimsel Adalet boyutunda .78 şeklindedir, ölçeğin tamamı için .86 bulunmuştur. Yine mevcut araştırma kapsamında, Örgütsel Adalet ölçeğinin yap1 geçerliliğini belirlemek amacıyla doğrulayıcı faktör analizi yapılmıştır. Örgütsel Adalet ölçeğinin orijinal formu 20 maddeden oluşmaktadır. Yapılan doğrulayıcı faktör analizi yoluyla kabul edilebilir düzeyde uyum iyiliği değerleri elde edilene kadar Dağıtımsal Adalet boyutundan iki madde (2 ve 3), İşlemsel Adalet boyutundan üç madde (8, 10 ve 11) ve Etkileşimsel Adalet boyutundan dört madde $(12,13,14$ ve 15) olmak üzere dokuz madde ölçekten çıkarılmıştr. Bu haliyle, ölçeğin DFA uyum iyiliği değerleri kabul edilebilir düzeye gelmiştir $(\mathrm{x} 2 / \mathrm{df}=2,13$; GFI= ,927 ; AGFI= ,883 ; CFI= ,944 ; NFI= ,901; TLI = ,925; RMSEA; ,076; SRMR= ,049). Bu işlemden sonra kalan maddeler tekrar numaralandırılarak 11 maddelik ölçek oluşturulmuştur. 
2.3.2. Minnessota Doyum Ölçeği: Öğretmenlerin iş doyumunu ölçmek üzere Weiss, Davis England \& Lofquist (1967) tarafindan geliştirilen ve Oran (1989) tarafindan Türkçeye uyarlanan Minnessota Doyum Ölçeğinin orijinali için hesaplanan Cronbach Alpha katsayıs1. 83'dür (Niehoff \& Moorman, 1993).Ölçeğin Türkiye'deki geçerlilik ve güvenirlik çalışması Yıldırım (1996) tarafından yapılmış, test-tekrar test güvenirlik katsayısı .76 iç tutarlılık katsayısı .90 olarak bulunmuştur. İş doyum ölçeğinin mevcut araştırma için hesaplanan Cronbach Alpha katsayısı ise .89'dur. Ayrıca, orijinal formu 20 madde ve tek boyuttan oluşan ölçeğin yap1 geçerliliğini belirlemek amacıyla, doğrulayıcı faktör analizi uygulanmıştır. Bu analiz sonucunda kabul edilebilir düzeyde uyum iyiliği değerleri elde edilene kadar sekiz madde ölçekten çıkarılmıştır $(2,5,6,7,8,9$, 13 ve 18). Sekiz madde çıarıldıktan sonra ölçeğin DFA uyum iyiliği değerleri, kabul edilebilir düzeye gelmiştir (x2/df=2,23; GFI= ,914; AGFI= ,876; CFI= ,911; NFI= ,852; TLI= ,891 ; RMSEA; ,079 ; SRMR= ,053). $\mathrm{Bu}$ işlemden sonra kalan maddeler tekrar numaralandırılarak 12 maddelik ölçek oluşturulmuştur.

Ölçekler Likert tipi beşli derecelendirme yoluyla hazırlanmıştır.(Kesinlikle katılmıyorum, Katılmıyorum, Kararsızım, Kattlıyorum ve Kesinlikle katıllyorum). Puan ortalamaları hesaplanırken aralıklar aşağıdaki gibi değerlendirilmiştir: 1,00-1,80 = Kesinlikle katılmıorum; 1,81-2,60 = Katılmıorum; 2,61-3,40 = Kararsızım; 3,41-4,20 Kat1lyorum; 4,21-5,00 Kesinlikle katıllyorum. İş Doyumu Ölçeğinde ise puan ortalamaları hesaplanırken aralıklar aşağıdaki gibi değerlendirilmiştir: 1,00-1,80 = Hiç memnun değilim; 1,81-2,60 = Memnun değilim; 2,61-3,40 = Kararsızım; 3,41-4,20 Memnunum; 4,21-5,00 Çok memnunum.

\subsection{Verilerin Analizi}

Örgütsel Adalet ve İş Doyumu ölçekleri aracilığıyla elde edilen verilerin analizinde SPSS 21.0 paket programından yararlanılarak, aritmetik ortalama, standart sapma ve Pearson momentler çarpımı korelasyon katsayısı hesaplanmıştır. Aritmetik ortalamalar tek başına yeterli bilgi vermediği için standart sapmalar ve bunlardan yararlanılarak bağıl değişkenlik katsayısı hesaplanmıştır. Öğretmen algılarının birbirine yakınlık ya da uzaklıklarını belirlemek amacıyla bağıl değişkenlik katsayısı $(V=\overline{\mathbf{x}} / \mathrm{SS}$ x 100) hesaplanmıştur. Normal dağılımlı bir veri grubunda bağıl değişkenlik katsayısı 20-25 arasında değişir. Bağıl değişkenlik katsayısının 20'den küçük ç1kması, standart sapmanın aritmetik ortalamaya göre küçük olması, 25’ten büyük çıkması ise standart sapmanın aritmetik ortalamaya göre büyük olması anlamına gelir. Standart sapma aritmetik ortalamaya göre küçükse, puanlar birbirine yakın, başka bir deyişle dağılım sivri ve homojendir. Standart sapma aritmetik ortalamaya göre büyükse, puanlar birbirine uzak, başka bir deyişle dağılım basık ve heterojendir (Karaca, 2008: 264).

\section{BULGULAR}

Bu bölümde araştırmaya ait bulgular tablolar eşliğinde verilerek açıklanmaya çalışılmıştır.

Liselerde görev yapan öğretmenlerin örgütsel adalet boyutlarına ilişkin alg1 ortalamaları, standart sapmaları ve bağıl değişkenlik katsayıları Tablo 1'de yer almaktadır.

Tablo 1. Lise Öğretmenlerinin Örgütsel Adalet Alg1ları

\begin{tabular}{lcccc}
\hline Boyut & $\mathbf{N}$ & $\overline{\mathbf{x}}$ & SS & V \\
\hline Dağıtımsal Adalet & 401 & 3.73 & .909 & 24.37 \\
Işlemsel Adalet & 401 & 3.65 & .943 & 25.84 \\
Etkileşimsel Adalet & 401 & 3.53 & .828 & 23.46 \\
Toplam & $\mathbf{4 0 1}$ & $\mathbf{3 . 6 4}$ & $\mathbf{. 8 9 3}$ & $\mathbf{2 4 . 5 3}$ \\
\hline
\end{tabular}

Tablo 1 incelendiğinde öğretmenlerin örgütsel adaletin bütün boyutlarındaki algiları kattlıorum düzeyinde $(\overline{\mathrm{x}}=3.41-4.20)$ gerçekleşmiştir. Algılar, dağıtımsal adalet boyutunda $\overline{\mathrm{x}}=\mathbf{3 . 7 3}$, işlemsel adalet boyutunda $\bar{x}=3.65$, Etkileşimsel Adalet boyutunda $\bar{x}=3.53$ düzeyindedir. Boyutların ortalamas1 ise $\overline{\mathrm{x}}=3.64$ değeri ile katlliyorum düzeyindedir. En yüksek katılım Dağıtımsal Adalet boyutunda, ikinci sırada İşlemsel Adalet boyutunda, en düş̧ukk kattlım ise Etkileşimsel Adalet boyutunda gerçekleşmiştir.

Bağıl değişkenlik katsayısına göre, İşlemsel Adalet boyutunda öğretmen algılarının birbirinden farklılaştuğ1, başka bir ifade ile bazı öğretmenlerin yüksek algılara sahip olmasına rağmen bazılarının düşük algılara sahip olduğu görülmektedir. Öğretmen görüşleri birbirinden uzak olup heterojen bir görünüm vermektedir. Dağıtımsal Adalet ve Etkileşimsel Adalet boyutlarında ise öğretmen görüşleri birbirine yakın, yani homojendir. 
Öğretmenlerin iş doyumu algılarını belirlemek için uygulanan Minnessota Doyum Ölçeği yoluyla elde edilen ortalamalar ve standart sapmalar Tablo 2'de yer almaktadır.

Tablo 2. İş Doyumu Algıları Ortalama ve Standart Sapmaları

\begin{tabular}{|c|c|c|c|c|}
\hline Maddeler & $\mathbf{n}$ & $\overline{\mathbf{x}}$ & SS & V \\
\hline 1. Şimdiki işimden bana meşguliyet sağlaması bakımından & 401 & 3.80 & .962 & 25.32 \\
\hline 2. Ara sıra değişik şeyler yapabilme şansımın olması bakımından & 401 & 3.25 & 1.180 & 36.31 \\
\hline 3. Toplumda "saygın bir kişi" olma şansını bana vermesi bakımından & 401 & 3.34 & 1.276 & 38.20 \\
\hline 4. Kişilere ne yapacaklarını söyleme şansına sahip olma bakımından & 401 & 3.44 & 1.094 & 31.80 \\
\hline 5. Kendi yeteneklerimi kullanarak bir şeyler yapabilme şansımın olması açısından & 401 & 3.69 & 1.108 & 30.02 \\
\hline 6. İş ile ilgili alınan kararların uygulamaya konması bakımından & 401 & 3.29 & 1.060 & 32.22 \\
\hline 7. İş içinde terfi olanağımın olması açısından & 401 & 2.89 & 1.180 & 40.83 \\
\hline 8. Kendi kararlarımı uygulama serbestliğini bana vermesi bakımından & 401 & 3.16 & 1.184 & 37.47 \\
\hline 9.İşimi yaparken kendi yöntemlerimi kullanabilme şansını bana sağlaması açısından & 401 & 3.58 & 1.127 & 31.48 \\
\hline 10. Çalışma şartları açısından & 401 & 3.20 & 1.195 & 37.34 \\
\hline 11. Yaptığım iyi bir iş karşıllı̆ında takdir edilmem açısından & 401 & 3.07 & 1.236 & 40.26 \\
\hline 12. Yaptığım iş karşılığında duyduğum başarı hissinden & 401 & 3.77 & 1.086 & 28.80 \\
\hline Toplam & 401 & 3.37 & 1.11 & 32.94 \\
\hline
\end{tabular}

Tablo 2'ye göre yönetici ve öğretmenlerin iş doyumu algılarının kararsızım $(\overline{\mathbf{x}}=2.61-3.40)$ ve memnunum $(\overline{\mathrm{x}}=3.41-4.20)$, aralığına denk geldiği görülmektedir. Ölçeğin 2., 3., 6. 7. 8. 10. ve 11. maddelerine yönelik katılımcı görüşleri Kararsızım diğer maddelere yönelik görüşleri ise Memnunum düzeyinde gerçekleşmiştir.

Örgütsel adalete yönelik ölçekte yer alan maddelere ilişkin görüşlerin "Katulyyorum" $\overline{\mathrm{x}}=3.41-4.20)$ düzeyinde olduğu göz önüne alınırsa, işgörenlerin örgütsel adalet alg1larının iş doyumlarından daha yüksek olduğu görülmektedir. İş doyumu aritmetik ortalaması $(\mathbf{x}=3.37)$ temel alındığında, katılımcıların yaptıkları işten doyum sağladıkları söylenemez. Bununla birlikte bağıl değişkenlik katsayısının ortalamada çok yüksek $(\mathrm{V}=32.94)$ çıkması, katılımcı görüşlerinin bütün maddelerde birbirinden oldukça fazlasıyla farklılaştığını göstermektedir. Başka bir ifadeyle, yönetici ve öğretmenlerin bazılarının iş doyumu çok yüksek iken bazılarının iş doyumu da çok düşük düzeydedir. Özellikle "İşs içinde terfi olanağımın olması açısından" ifadesini içeren madde ile ilgili görüşler $(\overline{\mathrm{x}}=2.89)$ "Kararsızım” düzeyinde gerçekleşmiş ve bağıl değişkenlik katsayısı çok yüksek (V=40.89) çıkmıştır. Bu bulgu, öğretmenlerin, terfi etme ve görevinde yükselme imkânlarını düşük algıladıklarını göstermektedir. Bağıl değişkenlik katsayısının yüksekliği de görüşlerin çok fazlasıyla farklılık gösterdiğini ortaya koymaktadır.

Öğretmenlerin İş Doyumu ile Örgütsel Adalet boyutlanı arasındaki ilişkiyi gösteren Korelasyon Analizi Sonuçları Tablo 3’te yer almaktadır.

Tablo 3. İş Doyumu ile Örgütsel Adalet Arasındaki İlişki

\begin{tabular}{lcccccc}
\multicolumn{1}{c}{ Ölçek } & $\overline{\mathrm{X}}$ & SS & İş Doyumu & $\begin{array}{c}\text { Dağıtımsal } \\
\text { Adalet }\end{array}$ & $\begin{array}{c}\text { İşlemsel } \\
\text { Adalet }\end{array}$ & $\begin{array}{c}\text { Etkileşimsel } \\
\text { Adalet }\end{array}$ \\
İş Doyumu & 3.38 & .774 & 1 & & & \\
Dağıtımsal Adalet & 3.72 & .915 & $501^{* *}$ & 1 & & \\
İşlemsel Adalet & 3.65 & .944 & $482^{* *}$ & $670^{* *}$ & 1 & 1 \\
Etkileşimsel Adalet & 3.54 & .832 & $516^{* *}$ & $589^{* *}$ & $777^{* *}$ & 1 \\
\hline
\end{tabular}

${ }^{* *} \mathrm{p}<, 01$

Tablo 3'te yer alan veriler, iş doyumu ile örgütsel adaletin üç boyutu ve bu üç boyutun kendi arasında .01 düzeyinde anlamlı bir ilişki olduğunu göstermektedir. İş doyumu ile dağıtımsal adalet (r= .501), işlemsel adalet $(\mathrm{r}=.482)$ ve etkileşimsel adalet $(\mathrm{r}=.516)$ boyutları arasındaki ilişki orta düzeydedir. Diğer yandan, dağıtımsal adalet ile işlemsel adalet $(r=.670)$; dağıtımsal adalet ile etkileşimsel adalet $(r=.589)$ ve işlemsel adalet ile etkileşimsel adalet $(r=.777)$ arasındaki ilişki, bu boyutların iş doyumu ile olan ilişkisinden daha güçlüdür. Örgütsel adalet ve iş doyumu arasında pozitif ve anlamlı bir ilişki vardır. Başka bir deyişle, örgütsel adalet algısı arttıkça iş doyumu da artmaktadır ya da iş doyumu arttıkça örgütsel adalet algısı da artmaktadır.

\section{TARTIŞMA, SONUÇ VE ÖNERİLER}

Liselerde görev yapan öğretmenlerin kendi okullannda var olan örgütsel adalete yönelik alg1lan "katılıyorum” düzeyinde gerçekleşmiştir. En yüksek algılar Dağıtımsal Adalet boyutunda ikinci sırada Isşlemsel 
Adalet boyutunda en düşük algılar ise Etkileşimsel Adalet boyutunda ortaya çıkmıştır. Örgütsel adalet ile iş doyumu arasında pozitif ve anlamlı bir ilişki bulunmuştur. Literatür incelendiğinde birçok çalışmada benzer sonuçlara ulaşıldığ1 görülmektedir (Atalay, 2005; Tan, 2006; Polat, 2007; Söyük, 2007; Cömert, Demirtaş, Üstün \& Özer, 2008; Polat \& Celep; 2008; Titrek, 2009; Altınkurt \& Yllmaz, 2010; Fatihma, Amiraa \& Halim, 2011; Aslam, Shumaila, Sadaqat, Bilal \& İntizar, 2012; Thomas \& Nagalingappa, 2012). Mevcut araştırma bulguları, daha önceden yapılan araştırmaların bulguları ile paralellik göstermektedir. Ruder (2003), işlemsel adaletin örgüte olan güvende istatistiksel olarak büyük bir öneme sahip olduğu bulgusuna ulaşmıstır. Polat \& Celep (2008), öğretmenlerle yürüttükleri çalışmada öğretmenlerin örgütsel adalet alg1 düzeylerini üç alt boyutta da “yüksek” bulmuşlardır. Oğuz (2011) yaptığı araştırmada öğretmenlerin okullarında örgütsel adalet algıları ile ilgili olarak olumlu görüşlere sahip olduklarını bulmuştur. Thomas \& Nagalingappa (2012) tarafindan yapılan araştırma sonucunda, etkileşimsel adaletin işlemsel ve dağıtımsal adaletten daha etkili olduğu bulunmuş ve dağıtımsal adaletin etkileşimsel adaletten daha fazla kullanıldığı saptanmıştır. Mohammad (2012), okul müdürleri ile ilgili yaptığı çalışmasında örgütsel adaletin bütün boyutlarında sonuçların yüksek çıktığını gözlemlenmiştir.

İşgörenlerin örgütsel adalet ile ilgili algıları işe karşı tutumlarını ve örgütsel davranışlarını etkiler. Bir iş yerinde örgütsel adalete yönelik algıların yüksek olması, yöneticilerin çalısanlara saygı1ı davrandıklarının ve onlara güvendiklerinin göstergesi olarak kabul edilebilir. Yüksek adalet algısı, aynı zamanda işgörenlerin yöneticilerine ve işyerlerine karşı güvenlerinin yüksek olduğu şeklinde de yorumlanabilir. Özellikle eğitim kurumlarında öğretmenlerin örgütsel adalet algılarının yüksek olması, onların kurumlarını sahiplendiğinin bir göstergesidir. Bu durumda, bütün öğretmenlerin okulu sahiplenerek "bu, benim okulumdur" diyebilmeleri beklenir.

Örgütsel adalet algısının yüksek olması, hem örgüt hem de işgörenler açısından çok önemlidir. Çünkü örgütsel adalet algısından etkilenen iş doyumunun, örgütsel vatandaşlık davranışlarını ve örgütsel bağl1lı̆̆1 yükseltme yoluyla örgütsel verimliliği yükseltmesi beklenir. Bununla birlikte, işgörenlerin iş yaşamında yakaladığı doyumun özel yaşamlarını da etkilemesi kuvvetle muhtemeldir. Olumlu adalet algısı; işgörenlerin kendilerini örgütün değerli ve saygın üyeleri olarak hissetmelerini, çalışma arkadaşları ve yöneticileriyle uyumlu ve güvene dayalı ilişkiler geliştirmelerini sağlayabilir.

İş doyumu ölçeğinde yer alan maddelere yönelik öğretmen görüşlerinin örgütsel adalet algisına göre daha düşük olduğu ve görüşler arasında yüksek düzeyde farklılıkların olduğu ortaya çıkmıştır. Bazı öğretmenler yüksek, bazıları da düşük iş doyumuna sahiptir. Özellikle düşük düzeyde iş doyumuna sahip eğitim işgörenlerinin işlerinden doyum elde etmelerine engel olan durumların belirlenmesinin ve okuldan ya da yönetimden kaynaklanan olumsuzlukların ortadan kaldırılmasının gerekli olduğu görülmektedir. Bu yolla, Demirel'in (2006), sözünü ettiği öğretmenler arasındaki düşük iş doyumunun muhtemel sonuçları (kendini yeterince işine verememe; işe ve yöneticilere karşı olumsuz tavırlar takınma, işe devam oranlarında düşüş; düşük verimlilik düzeyi ve okul değiştirme isteği) ortadan kaldırılabilir ya da hafifletilebilir.

Öğretmenler, işlerinde terfi olanaklarını hem düşük görmüşlerdir hem de bu maddeye yönelik algılar arasında büyük farklılıklar ortaya çıkmıştır. Özellikle bazı öğretmenler, terfi etme ve görevinde yükselme imkânlarının olmadığını düşünmektedirler. Yaptıklanı işten iş doyumunu yakalamayan ve görevinde yükselme olanağının çok düşük olduğunu düşünen öğretmelerin kendilerini işlerine yeterince veremeyecekleri söylenebilir. Bu öğretmenler, işe ve yöneticilere karşı olumsuz tavırlar takınarak, düşük düzeyde motivasyonla işe devam edebilirler. Böylece düşük performans ve verim sergileyerek kurumların etkililiğini ve öğrencilerin akademik başarısını düşürebilirler. Mevcut araştırma bulgularının aksine Karataş \& Güleş (2010) öğretmenlere yönelik yaptıkları araştırmada, öğretmenlerin iş doyumunu ortalamanın üzerinde bulmuşlardır.

İş doyumu ile dağıtımsal adalet işlemsel adalet ve etkileşimsel adalet boyutları arasındaki ilişki orta düzeyde ve anlamlı bulunmuştur. Diğer yandan, örgütsel adaletin üç boyutu arasındaki ilişki, bu boyutların iş doyumu ile olan ilişkisinden daha güçlüdür. Fatimah Amiraa \& Halim (2011), yaptıkları çalışmada iş doyumu yüksek olan öğretmenlerin örgütsel adalet algılarının da yüksek olduğunu ortaya koymuşlardır. Ayrıca dağıtımsal ve işlemsel adaletle karşılaştırılarak etkileşimsel adaletin iş doyumuyla en yüksek korelasyona sahip 
olduğu bulgusuna ulaşarak, örgütsel adaletin öğretmenlerin iş doyumunu etkilemede önemli roller oynadığını vurgulamışlardır. Aslam, Shumaila, Sadaqat, Bilal \& İntizar, (2012), örgütsel adalet ve iş doyumu arasında olumlu ve çok önemli bir ilişkinin olduğunu vurgulamıslardır. Bu, örgütsel adaletin iş doyumunu beraberinde getirdiği anlamına gelir. Örgütsel adaletin olduğuna inanan işgörenler daha memnun ve tatminkâr olduklarını hissettirmektedirler. Bu yüzden, iş doyumu gibi olumlu düşünce ve davranışları arttırmak ve örgütsel adalet sistemini geliştirmek için çaba gösterilmelidir. Söyük (2007) tarafından, örgütsel adalet algısının üç boyutunun da iş doyumu ile ilişkili olduğu tespit edilmiş ve örgütsel adalet algıları ile iş doyumu arasında orta düzeyde anlamlı ilişkiler bulunmuştur. Yıldırım (2007), dağıtımsal adalet, işlemsel adalet ve etkileşimsel adaletin tek başına iş doyumunu anlamlı bir şekilde etkilediğini; ancak, etkileşimsel adaletin daha güçlü açılama gücüne sahip olduğunu saptamıştır.

Ödüllerin ve kaynakların adil bir şekilde pay edilmesi, küçük birimlerden tüm topluma kadar her sosyal sistemde gerçekleşen evrensel bir olgudur. Ödül ve ceza olarak kaynakların dağıtımı sorunu gruplar, örgütler ve toplumun tümünü ilgilendirmektedir (Yıldırım, 2002: 28). Toplumsal bir özelliğe sahip olan eğitim kurumlarına yönelik bütün toplumun beklentileri mevcuttur. Eğitim kurumlarında, çocukların ve gençlerin eğitilmesi yolu ile toplumun bu beklentileri karşılanmaya çalışılır. Diğer yandan eğitim kurumlarının öğretmenlerin beklentilerini de karşılamaları beklenir. Öğretmenlerin kendi okullarında örgütsel adaletin sağlandığına yönelik algılarının yüksek olması onların beklentilerinin karşılandığının bir belirtisi olarak kabul edilebilir. Öğretmenlerin kendi okullarında örgütsel adaletin mevcut olduğu; ödüllerin ve cezaların verilmesinde adil olunduğu; kurumun bütün süreçlerinin (terfi, ders dağılımı, nöbet günleri, ders programlarının oluşturulması vb.) adil bir şekilde işlediği; yöneticilerin okulun işleyişinde hiçbir işgörene karşı negatif ya da pozitif ayrımcılık yapmadığı yönünde öğretmenleri yeterince bilgilendirmesi önemlidir. Buna bağlı olarak, öğretmenlerin örgütsel adalet algıları ve işlerinden elde ettikleri doyum da yükselebilir. Öğretmenlerin örgütsel adalet algılarını artırmada onları kendilerini ilgilendiren kararlara katmanın önemli bir etkisi olduğu göz önüne alınmalıdır. Bu araştırmanın sonucunda elde edilen bulgular ışığında aşağıdaki öneriler sunulabilir:

1. Etkileşimsel adalete yönelik algıların diğer boyutlara nispeten daha düşük düzeyde olması, eğitim kurumlarında işgörenler arasında iletişimin istenen düzeyde olmadığını göstermektedir. Okul yöneticileri, okullarında yatay, dikey ve çapraz iletişimi etkili kılarak etkileşimsel adalete yönelik öğretmen algılarını yükseltebilirler.

2. Araştırmaya göre, öğretmenlerin örgütsel adaletin dağıtımsal boyutundaki alg1 düzeyleri diğer iki boyutta göre biraz daha yüksek çıkmıştır. Terfi ve ücretlerin kurum dışında ana merkezden yapılmıs olmasının buna etkisi yüksektir ancak eğitim kurumlarında yöneticilik yapanların, öğretmenler arasında örgütsel adalet algısını (özellikle işlemsel adalet boyutunu) dengede tutabilmek için, kurum içinde yapılan ders, görev ve kaynakların dağıtımında tarafsız ve adilce davranarak bu işlerde şeffaflık ilkesini uygulamalıdır.

3. Eğitim kurumlarında karar verici konumundaki yöneticiler, örgütsel adalet algısını olumsuz yönde etkileyebilecek olan keyfi uygulamalardan kaçınmalıdır.

4. Okullarda demokratik ve özgür ortamların oluşturulması için tüm işgörenlerin kendilerini rahatlıkla ifade etmelerine imkân verilmeli, adil ve şeffaf bir yönetişim anlayışı geliştirilmelidir.

5. Araştırma sonucuna göre, öğretmenlerin mesleklerinde terfi ve yükselme ile ilgili algılarının oldukça düşük çıkması düzleminde yönetici atama ve yükselme durumlarında mülakattan vazgeçmeli ya da mülakatın değerlendirmedeki oranı düşürülmelidir.

6. Bu araştırmanın bazı sınırlıkları bulunmaktadır. Araştırmanın birinci sınırlılığı eğitim sektörü ile sınırlandırılması. İkinci sınırlılığı ise Bitlis İli, Adilcevaz, Ahlat ve Tatvan İlçelerindeki liselerde görev yapan öğretmenlere yapılmasıdır. Bu açıdan farklı sektörlerde ve farklı örneklemler üzerinde araştırma yapılmasının genelleme açısından uygun olacağı düşünülebilir. Örgütsel adalet ve iş doyumu ilişkisinin değerlendirilmesinde bu araştırmanın sonuçlarının yeterli olmayacağı açıtır. Örgütsel adalet ve iş doyumu algıları kişiden kişiye, kurumdan kuruma, bölgeden bölgeye ve hatta o anki ortama göre farklllkklar gösterebilir. Gelecekte benzer konularda araştırma yapacak olan araştırmacılar bu farkllıkları göz önünde bulundurarak daha farklı 
sektörlerde daha fazla örneklem ile örgütsel adalet ve iş doyumunun yanına birkaç boyut daha ilave ederek değişik çalışmalar yapmaları önerilebilir.

\section{KAYNAKÇA}

Agho, A. O., Mueller, C. W. \& Price, J. L. (1993). Determinants of employee job-satisfaction: An empirical-test of a causal model. Hum. Relat. 46 (8), 1007-1027.

Altınkurt, Y. ve Yılmaz, K.(2010). Değerlere Göre Yönetim ve Örgütsel Adalet İlişkisinin Ortaöğretim Okulu Öğretmenlerinin Alg1larına Göre İncelenmesi, Educational Administration: Theory and Practice, 16 (4), $463-484$.

Aslam, R., Shumaila, S., Sadaqat, S., Bilal, H. \& Intizar, M. (2012). Organizational justice as a predictor of job satisfaction among teachers - a case study on university of the punjab, Lahore.

Atalay, İ. (2005). Örgütsel Vatandaşllk ve Örgütsel Adalet (Yayınlanmamış yüksek lisans tezi). Kocatepe Üniversitesi, Sosyal Bilimler Enstitüsü, Afyon.

Bakhshi, A. (2009). Organizational Justice Perceptions As Predictor Of Job Satisfaction and Organization Commitment, International Journal of Business and Management, 4 (9), 146-149.

Brief, A. P. (1998). Attitudes in and Around Organizations, Thousand Oaks, CA: Sage, Brown,

Büyüköztürk Ş., Kilıç Çakmak, E,. Akgün, Ö.E., Karadeniz, Ş., Demirel, F. (2014). Bilimsel Araştrrma Yöntemleri, 18.Bask1, Ankara: Pegem Akademi.

Cömert, M., Demirtaş, H., Üstüner, M. ve Özer, N. (2008). Lise öğretmenlerinin örgütsel adalet alg1ları, Eğitim Bilimleri ve Uygulama, 7 (13), 3-22.

Cranny, C.L. Smith, P. \& Stone, F.F. (1992). Job Satisfaction: How People Feel About Their Job and How It Affects Their Performance, Lexington Books, New York.

Demirel, F. (2006). Sınf Öğretmenlerinin İs Doyum Dǚeyleri Denizli İli Örneği (Yayınlanmamış yüksek lisans tezi). Pamukkale Üniversitesi Sosyal Bilimler Enstitüsü, Denizli.

Demirtaş, H. (2010). Dershane Öğretmenlerinde Örgütsel Bağlllık ve İş Doyumu, İnönü Üniversitesi, Eğ̈tim Fakültesi Dergisi, Ağustos, 11 (2),185-200.

Demirtaş, Z. ve Ersözlü, A. (2010). Liselerde Görev Yapan Öğretmenlerin İş Doyum Düzeyleri "e-Journal of New World Sciences Academy Education Sciences," C0124, 5 (1), 199-209.

Eker, G. (2006). Örgütsel Adalet Algısı Boyutları ve İs Doyumu Üzerindeki Etkileri. (Yayınlanmamış yüksek lisans tezi). Dokuz Eylül Üniversitesi, Sosyal Bilimler Enstitüsü. İzmir.

Eren, E. (2011).Yönetim ve Organizasyon Çağdaş ve Küresel Yaklaşımlar (10. baskı), İstanbul: Beta Basım Yayın Dağıtım.

Fatimah, O. Amiraa, A. M. \& Halim, F. W. (2011). The Relationships between Organizational Justice, Organizational Citizenship Behavior and Job Satisfaction Pertanika J. Soc. Sci. \& Hum. 19 (S), 115 121 Universiti, Putra Malaysia Press

Gültekin, V.(1983). Hayat Ansiklopedisi. 1. Cilt, , Hakan Ofset. İstanbul: Doğan Kardeş Yayınları.

İşbaşı, J.Ö. (2000). Calışanlarn Yöneticilerine Duyduklarn Güvenin ve Örgütsel Adalete İlişkin Algzlamalarnnn Vatandaşlı. Davranısıınn Oluşumundaki Rolü, Bir Turizm Örgütünde Uygulama. (Yayınlanmamıs yüksek lisans tezi). Akdeniz Üniversitesi, Sosyal Bilimler Enstitüsü, Antalya.

İşcan, Ö.F. Naktiyok, A.(2004). Çalışanların Örgütsel Bağdaşımlarının Belirleyicileri Olarak Örgütsel Bağll1ık ve Örgütsel Adalet Alg1s1- Online 1-14 www. politics.ankara.edu.tr/dergi, adresinden 10 Ekim 2011 tarihinde indirilmiştir.

Karaca, E. (2008). Test ve Madde Analiži. İçinde: Eğitimde Ölçme ve Değerlendirme, Erkan, S. ve Gömleksiz, M. (Ed) Ankara: Nobel Yayıncilık.

Karakuş, A. (2008). Sağlık Meslek Lisesi Meslek Dersi Öğretmenlerinin İs Doyumlarna İlişkin Görüsleri. (Yayınlanmamış yüksek lisans tezi). Muğla Üniversitesi Sosyal Bilimler Enstitüsü, Muğla.

Karasar, N.(2011). Bilimsel Araştırma Yöntemi, (22.basım), Ankara: Nobel Yayın Dağıtım.

Karataş, S. ve Güleş, H. (2010). İlköğretim Okulu Öğretmenlerinin İş Tatmini ile Örgütsel Bağlllı̆̆1 Arasındaki İlişki, Ușak Unniversitesi Sosyal Bilimler Dergisi,3 (2), 74-89.

Lawler, E.E. (1987). Handbook of Organizational Behavior, New York: Prentice Hall.

Lund, D. (2003). Organizational culture and job satisfaction. Journal of Business and Industrial Marketing. 18- 3, USA: University of Nevada.

Misener, T.R., Haddock, K.S., Gleaton, J.U. \& Ajamieh, A.R. (1996). Toward an international measure of job satisfaction. Nursing Research, 45, 87-91.

Mohammad, S. L. M. (2012), The degree of organizational justice to the principals of public schools and their relationship to job satisfaction of teachers in public high schools in the districts of the northern West Bank." Educational Science - Educational Administration. 
Niehoff, B, P. Moorman, R, H. (1993), "Justiee as a Mediator of the Relationship Between Methods of Monitoring and Organization al Citizenship Behavior," Academy of Management Joumal, 36 (3), 527-556.

Oran, N. B. (1989). Job Satisfaction of a Group of Academical Staff in Marmara University. (Yüksek Lisans Tezi). Marmara Üniversitesi Sosyal Bilimler Enstitüsü, İstanbul.

Oğuz, E. (2011). Öğretmenlerin Örgütsel Adalet Alg1ları ile Yöneticilerin Liderlik Stilleri Arasındaki İlişki, Inönü Üniversitesi Eğitim Fakültesi Dergisi, 12 (1), 45-65.

Özdevecioğlu, M. (2003). Algılanan Örgütsel Adaletin Bireylerarası Saldırgan Davranışlar Üzerindeki Etkilerinin Belirlenmesine Yönelik Bir Araştırma. Erciyes Üniversitesi İktisadi ve İdari Bilimler Fakültesi Dergisi, (21), 77-96.

Özgan, H. ve Bozbayındır, F. (2011). Okullarda Adil Olmayan Uygulamalar Ve Etkileri, Dicle Üniversitesi Ziya Gökalp Ë̈itim Fakültesi Dergisi,16, 66-85,

Polat, S. (2007). Ortaögretim Ögrretmenlerinin Örgütsel Adalet Algzlar, Örgütsel Güven Düzeyleri ile Örgütsel Vatandaşlık Davramışlar Arasındaki İlişkei. (Yayınlanmamış doktora tezi). Kocaeli Üniversitesi Sosyal Bilimler Enstitüsü, Kocaeli.

Polat, S. ve Celep, C.(2008). Ortaöğretim Öğretmenlerinin Örgütsel Adalet, Örgütsel Güven, Örgütsel Vatandaşlık Davranışlanına İlişkin Algıları, Educational Administration: Theory and Practice Spring, (54),307331.

Ruder, G. J. (2003). The Relationship Among Organizational Justice, Trust, And Role Breadth Self-Efficacy, Dissertation submitted to the faculty of the Virginia Polytechnic Institute and State University in partial fulfilment of the requirements for the degree of Doctor Of Philosophy, Falls Church, Virginia,USA.

Sayın, U. (2009). Güven: Issletmelerde Algılanan Örgütsel Adalet Ve İs Tatmini Arasindaki İlişkide Bir Aracı - Bir Uygulama. (Yayınlanmamış yüksek lisans tezi) Atatürk Üniversitesi Sosyal Bilimler Enstitüsü, Erzurum.

Söyük, S. (2007). Örgütsel Adaletin İs Tatmini Üzerindeki Etkisi ve İstanbul İlindeki Özel hastanelerde Çalsan Hemșirelere Yönelik Bir Calşsma. (Yayınlanmamış doktora tezi). İstanbul Üniversitesi Sosyal Bilimler Enstitüsü, İstanbul.

Tan, Ç. (2006). İlköğretim okullarnnda Görev Yapan Öğretmenlerin Örgütsel Adalet Konusundaki Algzlar. (Yayınlanmamış yüksek lisans tezi). Fırat Üniversitesi Sosyal Bilimler Enstitüsü, Elazı̆̆.

Thomas,P, \& Nagalingappa,G. (2012). Consequences Of Perceived Organizational Justice: An Empirical Study Of White-Collar Employees, B.N.M Institute of Technology, BSK II Journal of Arts, Science \& Commerce, India: Stage, Bangalore.

Titrek, O. (2009). Okul türüne göre okullardaki örgütsel adalet düzeyi. Uluslararası İnsan Bilimleri Dergisi, 6 (2), $551-573$.

Weiss, D.J. R. Davis, R.V. England, G.E. \& Lofquist, L.H. (1967), Manual for the Minnesota Satisfartion Questionnaire, Minnesota Studies in Vocational Rehabilitation 22 Work Adjustment Project Industrial Relations Center University of Minnesota.

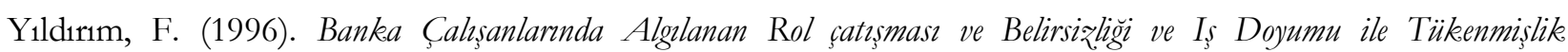
Arasındaki ilişki. (Yayınlanmamış Yüksek Lisans Tezi). Hacettepe Üniversitesi Sosyal Bilimler Enstitüsü, Ankara.

Yıldırım, F. (2002). Callşma Yaşamında Örgüte Bağhllk ve Örgütsel Adalet İlişkisi. (Yayınlanmamış Doktora Tezi). Ankara Üniversitesi Sosyal Bilimler Enstitüsü, Ankara.

Yıldırım, F.(2007). İş Doyumu İle Örgütsel Adalet İlişkisi, Ankara Üniversitesi Siyasal Bilgiler Fakeültesi Dergisi, 62 (1), 253-278.

Yürür, S.( 2008), “Örgütsel Adalet ile İş Tatmini ve Çalışanlanın Bireysel Özellikleri Arasındaki İlişkilerin Analizine Yönelik Bir Araştırma”, Süleyman Demirel Üniversitesi İIBF Dergisi, 13 (2),295-312.

\section{Citation Information}

Demirtaş, Z. \& Kılıç, Y. (2016) Lise Öğretmenlerinin Örgütsel Adalet ve İş Doyumu Algıları Arasındaki İlişki Düzeyleri. Dicle Üniversitesi Ziya Gökealp Ë̆itim Fakültesi Dergisi, 28, 259-267. 